КЕРІВНИЦТВО МЕТОДИЧНОЮ РОБОТОЮ В ДИТЯЧИХ САДКАХ УКРАЇНИ У 30-тИХ РОКАХ ХХ СТОЛІТТЯ

\title{
MANAGEMENT OF METHODICAL WORK IN KINDERGARTENS OF UKRAINE IN THE 30S OF THE 20th CENTURY
} у статті розкрито особливості керів-
ництва методичною роботою в дитя-
чих садках України у З0-ті роки ХХ сто-
ліття. Форми методичної роботи, що
існували у 20-х роках ХХ століття, не
могли задовольнити вимог практичних
працівників, тому на початку 1931 року
методичну роботу в системі дошкіль-
ного виховання було реорганізовано, змі-
нено ї структуру.

Безпосереднє методичне керівництво повинна була здійснювати завідувачка дитячого садка. Основною формою методичного керівництва було безпосереднє спостереження за роботою вихователя з дітьми (прогулянки, ігри, заняття, режим дня). Особливо важливими були педагогічні наради, на яких обговорювалися особливості виховної роботи з дітьми, досвід роботи вихователів, педагоги звітувались про свою діяльність тощо.

Керівництво методичною роботою в дитячих садках також здійснював дошкільний інспектор районного відділу народної освіти. У його обов'язки входив контроль над усією роботою дитячих садків, ознайомлення педагогічних колективів із кращим досвідом роботи педагогів. У наданні методичної допомоги дитячим садкам інспектор керувався рекомендаціями, наданими методичними кабінетами. Методичними кабінетами організовувалися індивідуальні та групові консультації, гуртки, семінари, цикли лекцій та бесід з окремих питань, пересувні виставки, допомога в роботі з методичною літературою, здійснювалися заохочення до постійного підвищення професійної кваліфрікації педагогів дитячих садків.

Керівниитво методичною роботою в дитячих садках також здійснював районний методист. Основним його завданням була безпосередня допомога працівникам дитячих садків у реалізації завдань комуністичного виховання дошкільників, удосконалення методів та форм роботи з дітьми, відвідування дитячих садків, організація консультацій, лекцій, семінарів, узагальнення кращого педагогічного досвіду.
Ключові слова: методична робота, методичне керівничтво, методичне об'єднання, інспектор, методист.

The article reveals the peculiarities of the management of methodical work in kindergartens of Ukraine in the 30s of the 20th century. Peculiarities of development of public preschool education and methodical work during the specified period are disclosed. Forms of methodical work that existed in the 20s of the 20th century could not meet the requirements of practitioners, so in early 1931, methodical work in the system of preschool education was reorganized, its structure was changed.

The direct methodical management and control was exercised by the head of the kindergarten. The main form of methodical management was direct observation of the preschool teacher's work with children (walks, games, classes, all day in general). Especially important were the pedagogical meetings, where the features of educational work with children, the experience of preschool teachers were discussed, teachers reported on their activities and more.

The preschool inspector of the district department of public education also supervised the methodical work in kindergartens. His responsibilities included supervising all the work of kindergartens, acquainting teaching staff with the best experience of teachers.

In providing methodical assistance to kindergartens, the inspector relies on methodical offices. Methodical offices organized individual and group consultations, circles, seminars, cycles of lectures and conversations on certain issues, travelling exhibitions, assistance in working with methodical literature, encouraged the continuous improvement of professional skills.

Methodical work in kindergartens was also supervised by a district methodologist. His main task was to assist preschool teachers in realization of the tasks of communist education, improving methods and forms of working with children, attending kindergartens, organizing consultations, lectures, seminars, summarizing best practices and more.

Key words: methodical work, methodical management, methodical association, inspector, methodologist.
Постановка проблеми в загальному вигляді. Одним із пріоритетних напрямів державної освітньої політики в Україні $€$ розвиток дошкільної освіти, що передбачає підвищення вимог до рівня організації роботи закладів дошкільної освіти. Ефрективність роботи закладу дошкільної освіти залежить від рівня організації методичної роботи, що віддзеркалює вимоги суспільства до дошкільної освіти, зміни у змісті та технологіях навчання і виховання дітей дошкільного віку. Керівництво методичною роботою в дошкільному навчальному закладі необхідно переглянути 3 позиції науко- вого обґрунтування ефрективних фрорм та методів роботи, витоки яких знаходяться на попередніх етапах розвитку системи суспільного дошкільного виховання.

Аналіз останніх досліджень і публікацій. Загальні теоретичні аспекти методичної роботи в закладах освіти висвітлено у працях I. Жерносек, С. Майданенко, В. Павленко й інших; розкрито зміст, форми, особливості організації методичної роботи в сучасних закладах дошкільної освіти у працях Я. Бенцион, Г. Бєлєнької, К. Білої, А. Богуш, О. Долинної, І. Жерносек, О. Кононко, В. Крижко, 
К. Крутій, А. Морозової, Н. Савінової, Л. Швайки й інших. Генеза організації методичної роботи в радянській та вітчизняній освіті розглянута у працях А. Єрмоли, Л. Калініної, О. Капченко, Г. Литвиненко, Ю. Сирової, Т. Ткачевої й інших, але ці праці переважно розглядають розвиток методичної роботи у школі. Історико-педагогічні аспекти розвитку суспільного дошкільного виховання в Україні, зміст, фрорми, методи, планування освітнього процесу вивчали Л. Артемова, О. Бондар, 3. Борисова, О. Венгловська, О. Проскура, Т. Степанова, І. Улюкаєва й інші.

Виділення не вирішених раніше частин загальної проблеми. Різноманітність та багатоаспектність наукових досліджень не розкриває повною мірою проблему керівництва методичною роботою в дитячих садках України у 30-ті рр. XX ст.

Мета статті - розкрити особливості керівництва методичною роботою в дитячих садках України у 30-ті рр. XX ст. в єдності педагогічного досвіду, аналізу наукових досліджень, особливостей розвитку суспільного дошкільного виховання України в зазначений період.

Виклад основного матеріалу. У $30-т і$ рр. XX ст. в Україні на законодавчому рівні визначене місце суспільного дошкільного виховання як першої ланки освітньої системи [2, с. 283]. Створено широку мережу закладів суспільного дошкільного виховання, підвищився рівень матеріального та санітарно-гігієнічного забезпечення, уніфріковані типи закладів і зміст виховної роботи, розроблялись і затверджувались програмові матеріали. Велася активна робота щодо визначення змісту дошкільної освіти, упровадження нових наукових ідей у практику, підвищення квалісрікації та педагогічної майстерності вихователів дитячих садків, що вело до активного розвитку методичної роботи.

З 1931 р. в Україні починає видаватися щомісячний журнал «За комуністичне виховання дошкільника», що мав здійснювати методичне керівництво масового педагогічного працівника [7, с. 4], а також слугував для обміну кращим досвідом і популяризації ідей дошкільного виховання серед населення [9, с. 14].

До середини 30-х рр. XX ст. тривало фрормування радянської системи народної освіти. Наприкінці 1936 р. відбулася Республіканська нарада дошкільних працівників, де обговорювались питання про завдання методичного керівництва, планування й організації роботи дитячих садків [8, с. 16]. Для поліпшення і поглиблення виховної роботи 3 дітьми в усіх обласних центрах Української Радянської Соціалістичної Республіки і великих містах (Київ, Харків, Дніпропетровськ, Одеса й інші) було створено мережу обласних та міських кабінетів дошкільного виховання, що вивчали кращий досвід дитячих садків, популяризували його на методичних об'єднаннях та конференціях дошкільних працівників, на сторінках журналу «За комуністичне виховання дошкільника» [10, с. 17]. Для підвищення рівня методичного керівництва зусиллями обласних кабінетів дошкільного виховання й обміну досвідом роботи в 1939 р. при Народному комісаріаті освіти відкрився Центральний науково-методичний кабінет дошкільного виховання [1, с. 20].

Форми методичної роботи, поширені у 20-х рр. XX ст., не могли задовольнити вимог практичних працівників. Основна увага спрямовувалась на «проробки» програм дитячого садка, що призводило до формального ставлення вихователів до роботи з дітьми, не давало їм можливості зосередити свою увагу на виховній роботі. Вихователям надавалися трафраретні методичні розробки, конспекти занять. Інструктаж зазвичай проводився в рецептурній формі, без урахування досвіду вихователя та попередньої роботи. Працю вихователя оцінювали за формальними ознаками: станом планування й обліку, кількістю записів тощо. Більшість керівників дитячих садків основну увагу приділяли господарській роботі. Необхідно було докорінно перебудовувати роботу, внести низку істотних змін до здійснення методичного керівництва дитячими садками [5, с. 22].

На початку 1931 р. методичну роботу в системі дошкільного виховання було реорганізовано, змінено її структуру [3, с. 32]. При секції народної освіти міських рад організовувались методичні бригади, що поділялися на окремі групи: комуністичного виховання дітей; комуністичного виховання дорослих; професійної освіти. До складу методичної бригади входили також консультанти, інспектори з різних галузей методичної роботи. Наприклад, у місті Харкові було три райони, до кожного району прикріплено одного інструктораметодиста, що безпосередньо керував методичною роботою дитячих садків свого району. У кожному районі працював хоча б один опорний дитячий садок, що був центром методичної роботи. Крім цього, щоб зручніше керувати роботою, усі дитячі садки міста поділені на «кущі» по 5-6 закладів. Кожне з методичних об'єднань мало свої функції. Уся методична робота розглядалася й обговорювалася на загальних міських методичних конореренціях дошкільних працівників, а також на районних об'єднаннях. Питання поточної методичної роботи обговорювалися на «кущових» зборах. щоб системно опрацьовувати актуальні питання методичної роботи, кущові об'єднання проводились систематично, двічі на місяць, на них розглядалися результати інспектування дитячих садків, представники дитячих садків звітували про свою роботу. До здійснення методичної роботи залучалися активні педагоги дитячих садків, а також дошкільні секції науково-дослідницьких інститутів педагогіки [3, с. 33]. 
На секційному засіданні Третьої обласної конфреренції працівників дошкільних установ Дніпропетровської області (лютий 1937 р.) були розглянуті питання методичної роботи: розпорядок дня в дошкільній установі; методика роботи з розвитку мовлення; устаткування й оформлення дитячого садка; робота з батьками; система методичного керівництва. У резолюціях консреренції зазначено, що для підвищення якості методичного керівництва і методичної допомоги необхідно переймати досвід кращих майстрів дошкільної справи зразкових садків; організовувати методичні семінари 3 окремих методик дошкільного виховання; з метою забезпечення постійної методичної допомоги до сільського дитячого садка треба прикріпити дитячий садок міста; на посади завідувачок дитячих садків висувати кращих педагогів зі спеціальною педагогічною, дошкільною освітою; методичним кабінетам вивчати кращий досвід педагогічних працівників, щоб поширити його серед дошкільних установ району, області [4, с. 64-66].

Безпосереднє методичне керівництво і контроль повинна була здійснювати завідувачка дитячого садка, яка спрямовувала та перевіряла роботу вихователів. Завідувачка мала добре знати кожного вихователя, його слабкі та сильні сторони, особливості його роботи з дітьми. Однією 3 основних фрорм методичного керівництва повинно було стати безпосереднє спостереження за роботою вихователя з дітьми (прогулянки, ігри, заняття тощо) 3 наступними вказівками щодо методичних способів та прийомів, успіхів і недоліків у роботі вихователів. Особлива увага приділялася менш досвідченим педагогам.

Важливими були педагогічні наради, на яких обговорювалися особливості виховної роботи 3 дітьми, досвід роботи вихователів, педагоги звітували про свою діяльність тощо. В обговоренні питань брав участь увесь колектив закладу, вносили пропозиції щодо поліпшення роботи. Крім того, обговорювались окремі питання дошкільного виховання, заслуховувались доповіді педагогів, що відвідують семінари, гуртки. За результатами таких обговорень ухвалювалися рішення щодо підвищення якості педагогічного процесу, здійснювалась перевірка його виконання. У річному плані зазначалися основні питання, що потребують розгляду на педагогічних нарадах.

3 метою підвищення якості роботи завідувачка і кожен працівник дитячого садка повинні були систематично підвищувати свій ідейно-політичний і педагогічний рівень, навчатися в педагогічній школі чи в педагогічному інституті, а також відвідувати гуртки, методичні об'єднання, методичний кабінет, кращі дитячі садки [5, с. 23-24].

Керівництво методичною роботою в дитячих садках також здійснював дошкільний інспектор районного відділу народної освіти. У його обов'язки входив контроль над усією роботою дитячих садків, ознайомлення педагогічних колективів із кращим досвідом роботи. Інспектор мав надавати необхідну організаційну та методичну допомогу, водночас не порушувати «єдиноначальності» завідувачки дитячого садка. Він мав бути добре обізнаний в адміністративно-господарських питаннях роботи закладів, надавати допомогу у вирішенні проблем. В кожному закладі був журнал для записів інспектора, де фріксувались результати його перевірки, надання пропозицій, наслідки перевірки їх виконання. Інспектор мав добре знати роботу дитячих садків свого району, роботу окремих педагогів і завідувачів, насамперед допомагати і керувати роботою того дитячого садка, де неналежно забезпечене керівництво з боку завідувачки, водночас вживати заходів для підвищення кваліфрікації такої завідувачки або її заміни на більш кваліфікованого і досвідченого керівника.

У наданні методичної допомоги дитячим садкам інспектор керувався рекомендаціями методичних кабінетів, водночас не перекладав на них свої обов'язки. Перед методичними кабінетами 3 1937 р. було поставлено завдання - надавати систематичну допомогу в методичній роботі педагогам дитячих садків. Представники методичних кабінетів організовували індивідуальні та групові консультації, гуртки, семінари, цикли лекцій та бесід з окремих питань, пересувні виставки, допомогу в роботі з методичною літературою, заохочення до постійного підвищення професійної кваліфікації [5, с. 24-25]. Відділ народної освіти систематично керував роботою методичних кабінетів, затверджував їхні плани роботи, здійснював облік.

Кожен відділ народної освіти (дошкільний інспектор), кожен методичний кабінет, як обласний так і районний, повинні були знати кращі районні дитячі садки, кращих вихователів, завідувачів у своєму районі й області, популяризувати їхній досвід роботи. Особливо актуальним це стало у 30-і рр. XX ст., коли «зразкові дитячі садки» реорганізовано в масові. У цей період першочерговим завданням стала виховна робота 3 дітьми. На методичних об'єднаннях педагоги обмінювались кращим досвідом роботи, обговорювали актуальні питання дошкільного виховання. На таких об'єднаннях презентували доповіді інструктивного, теоретичного та практичного характеру, що розширювали кругозір і творчу ініціативність вихователів. Через ці об'єднання здійснювався масово-методичний інструктаж дошкільних працівників [5, с. 26].

Керівництво методичною роботою в дитячих садках також здійснював районний методист, він допомагав районному інспектору дошкільного виховання здійснювати методичне керівництво дошкільними закладами в районі. Основним його завданням була безпосередньо допомога праців- 
никам дитячих садків у реалізації завдань комуністичного виховання дітей дошкільного віку, удосконалення методів та фрорм роботи з дітьми. Щоб виконати ці завдання, методист мав добре знати програми дошкільних закладів, методики і техніки педагогічної роботи, практику роботи дитячих садків, роботу кожного дошкільного працівника, систематично підвищувати фрахову компетентність. Основними ділянками роботи районного методиста були: відвідування дитячих садків; організація консультацій, лекцій, семінарів тощо; систематична робота із завідувачками закладів; аналіз практики роботи садків, узагальнення кращого досвіду роботи, висвітлення його у пресі, керування методичними об'єднаннями [6, с. 28-29].

Висновки. 30-ті рр. XX ст. характеризуються реорганізацією радянської системи дошкільної освіти, створенням широкої мережі закладів суспільного дошкільного виховання, обґрунтуванням теоретичних, організаційних та методичних основ діяльності дитячих садків. 3'ясовано, що це період активного розвитку фрорм організації методичної роботи в системі дошкільного виховання. На початку 1931 р. методичну роботу в системі дошкільного виховання було реорганізовано, змінено її структуру. Узагальнюючи дані теоретичного дослідження, можемо констатувати, що безпосереднє методичне керівництво в дитячому садку здійснювала завідувачка, яка спрямовувала та перевіряла роботу вихователів. Керівництво методичною роботою в дитячих садках також здійснював дошкільний інспектор районного відділу народної освіти. У його обов'язки входив контроль над усією роботою дитячих садків, ознайомлення педагогічних колективів із кращим досвідом роботи. Методичну допомогу надавали дитячим садкам районні та міські методичні кабінети. Методичними кабінетами організовувались індивідуальні та групові консультації, гуртки, семінари, цикли лекцій та бесід з окремих питань, пересувні виставки, допомога в роботі з методичною літературою, здійснювалось заохочення до постійного підвищення профресійної кваліфрікації. До керівни- цтва методичною роботою в дитячих садках був залучений районний методист. Основним його завданням була безпосередня допомога працівникам дитячих садків у реалізації завдань комуністичного виховання дітей дошкільного віку, удосконалення методів та форм роботи 3 дітьми. Не всі прогресивні ідеї того часу, що стосувалися керівництва методичною роботою в дитячих садках, були втілені в життя. Це зумовлено специфікою соціально-політичної ситуації в державі. Тому вивчення історико-педагогічного досвіду в окреслених рамках дослідження розглядаємо як перспективне.

\section{БІБЛІОГРАФІЧНИЙ СПИСОК:}

1. Від редакції. За комуністичне виховання дошкільника. 1931. № 1. С. 4

2. Горова О. Структура та зміст метод роботи дошкільних установ. За комуністичне виховання дошкільника. 1931. № 3. С. 32-33.

3. Кузьменко У. Вказівки щодо організації та змісту методичного керівництва дитячими садками. За комуністичне виховання дошкільника. 1937. № 10. C. 22-28.

4. Про III обласну конференцію працівників дошкільних установ Дніпропетровської області. За комуністичне виховання дошкільника. 1937. № 5. C. 64-66.

5. Тарнопольська Г. Робота районного методиста. За комуністичне виховання дошкільника. 1937. № 10. C. 28-34.

6. Улюкаєва І. Історія суспільного дошкільного виховання в Україні : підручник. Київ : Видавничий дім «Слово», 2016. 424 с.

7. Центральний державний архів вищих органів влади та управління України. Ф. 166. Оп. 15. Спр. 2188. Арк. 14.

8. Центральний державний архів вищих органів влади та управління України. Ф. 166. Оп. 15. Спр. 2188. Арк. 16.

9. Центральний державний архів вищих органів влади та управління України. Ф. 166. Оп. 15. Спр. 2188. Арк. 17.

10. Центральний державний архів вищих органів влади та управління України. Ф. 166. Оп. 15. Спр. 2188. Арк. 20. 